life and in the adult condition in many mammals, between the vessels of the choroid and of the optic nerve round the edge of the disc.

In the present case, however, there is a definite aberrance of growth, in that some abnormal process has destroyed the membrane of Bruch and allowed of an anastomosis between retinal and choroidal vessels in a situation where this never occurs normally in mammalian ontogeny or phylogeny.

The freedom of the rest of the eye from any abnormality and the clear cut nature of the defect, seem to us to point to a single localised lesion at a definite time rather than to any inherent failure in organogeny.

It is in the belief that the explanation can be found in a localised patch of choroidal disturbance occurring during the fourth month and that the case falls into the class of atypical colobomata associated with abnormal vessels that we venture to publish it.

\title{
REFERENCES.
}

Beaumont, W. M.-Trans. Ophthal. Soc. U.K., Vol. XI, 1891.

Mann, Ida C. -Brit. Jl. of Ophthal., March, 1927.

\section{BUPHTHALMOS AND NAEVUS}

BY

\section{T. R. AynSLEY}

BOURNEMOUTH

I WISH to record four cases of buphthalmos presenting certain features in common. Two of the cases occurred in the course of my own work (E.R. and M.C.) and the other two I was able to examine at the Fountains Hospital.

Case 1. E.R., female, aged 9 years, imbecile. Extensive naevus on the face, scalp, left arm and left side of chest, also some patches on left buttock and thigh. The facial naevus has spread on to the right side of the face but at birth it was said to be confined to the left side. It extends on to the eyelids, but the conjunctiva is not affected. There is a right congenital hemiplegia and an X-ray plate of the skull shows a large calcified meningeal naevus (Fig. 1).

Left eye-cornea enlarged to about $13 \mathrm{~mm}$. Anterior chamber deep. No thinning of the sclera. Some dilated episcleral veins. Pupil reacted sluggishly to light. The iris stroma appeared much denser than in the right eye and the colour was grey green, the other being light blue (Fig. 2). Optic disc large and deeply 
BUPhTHALmos AND NaEvus

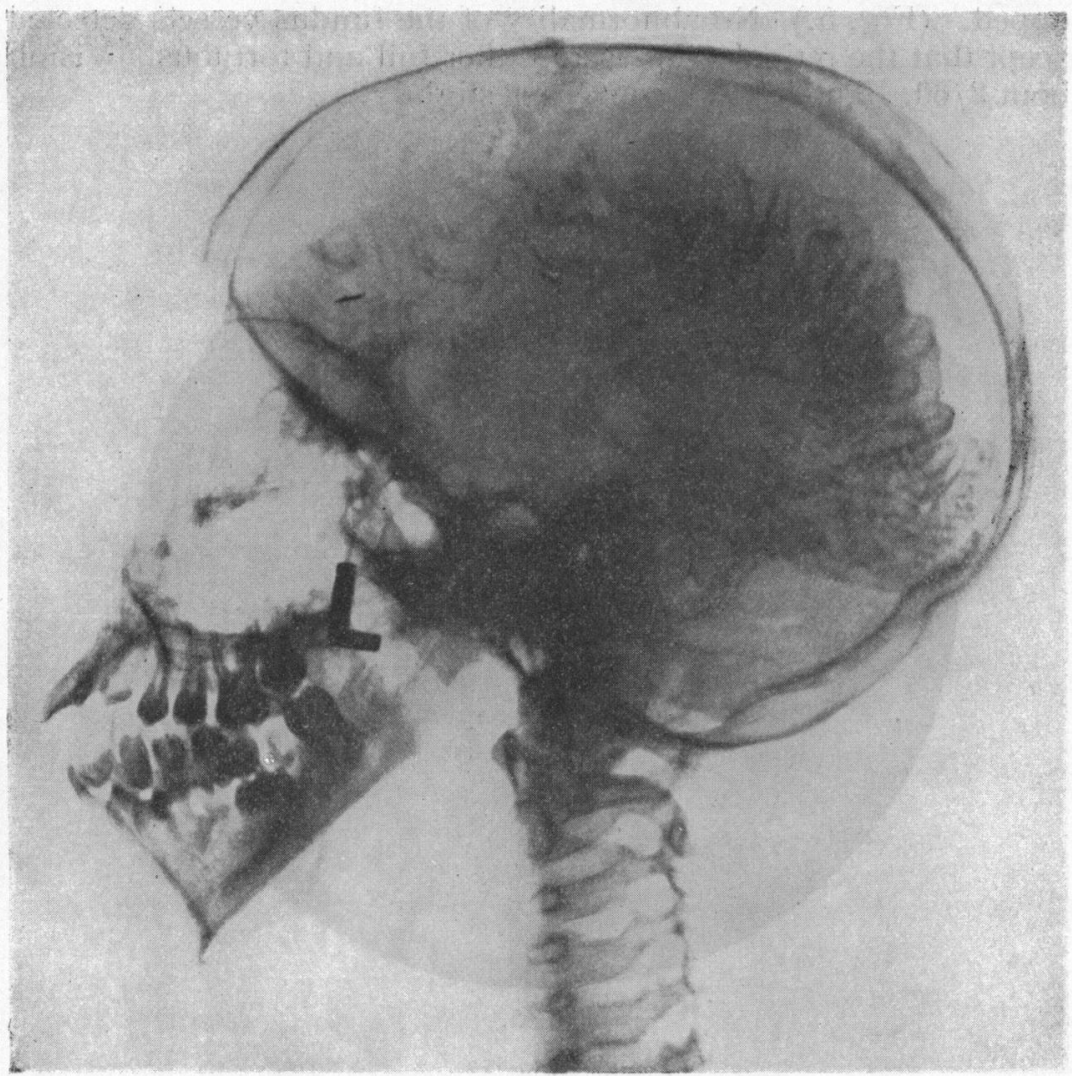

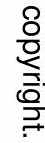

Fig. 1.

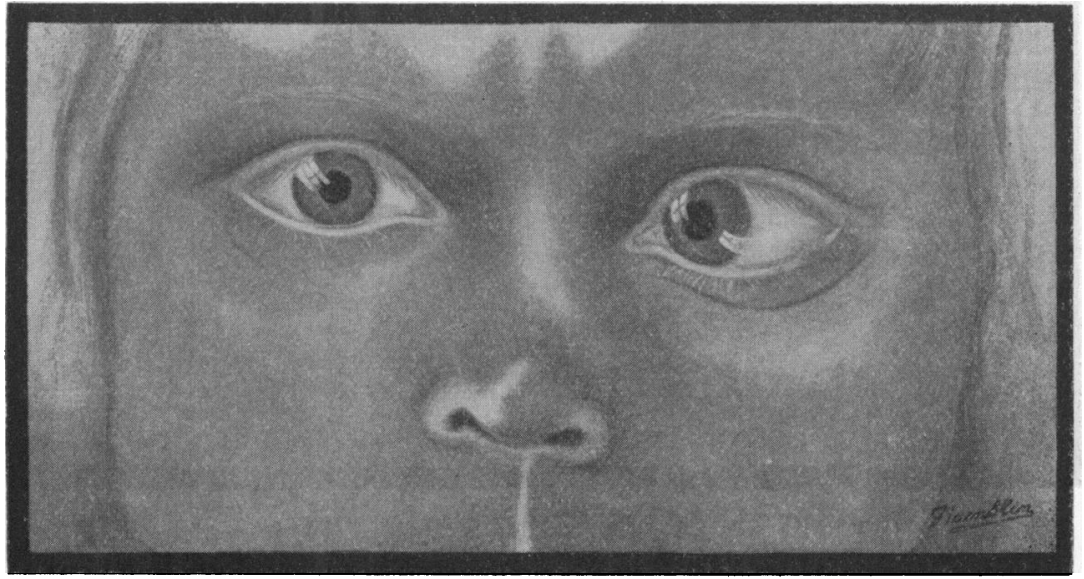

FIG. 2. 
cupped. (Fig. 5.) No abnormality of the fundus vessels detected except that the retinal veins were rather full and tortuous. Vision about $2 / 60$. The left eye converges slightly.
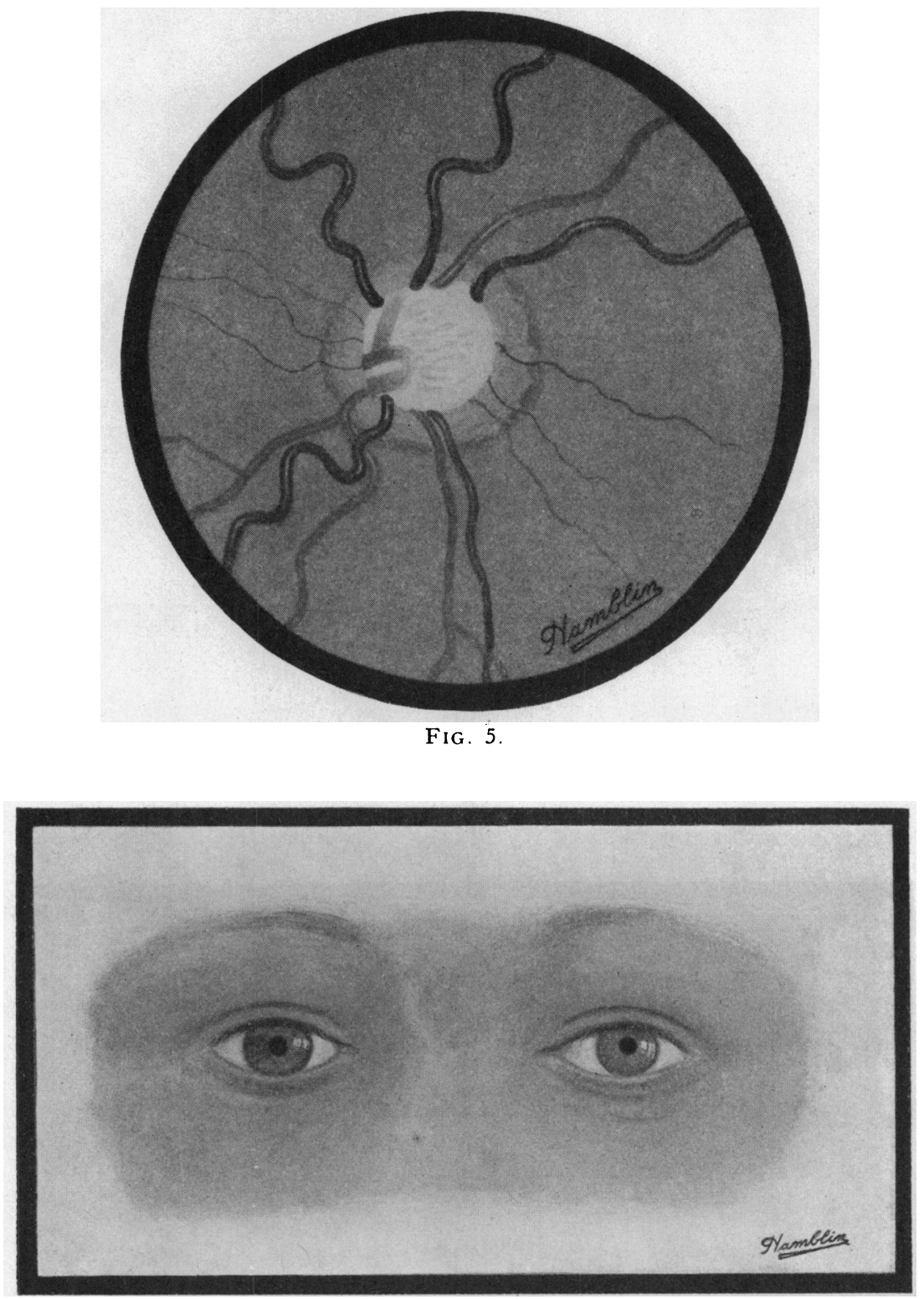

FIG. 3. 
Case 2. M.C., female, aged 6 years, imbecile. A naevus covers the right side of the face and scalp, ending in the mid line and involving half of the tongue, palate, and mucous membrane of the upper and lower jaws. There is a left hemiplegia. An X-ray of

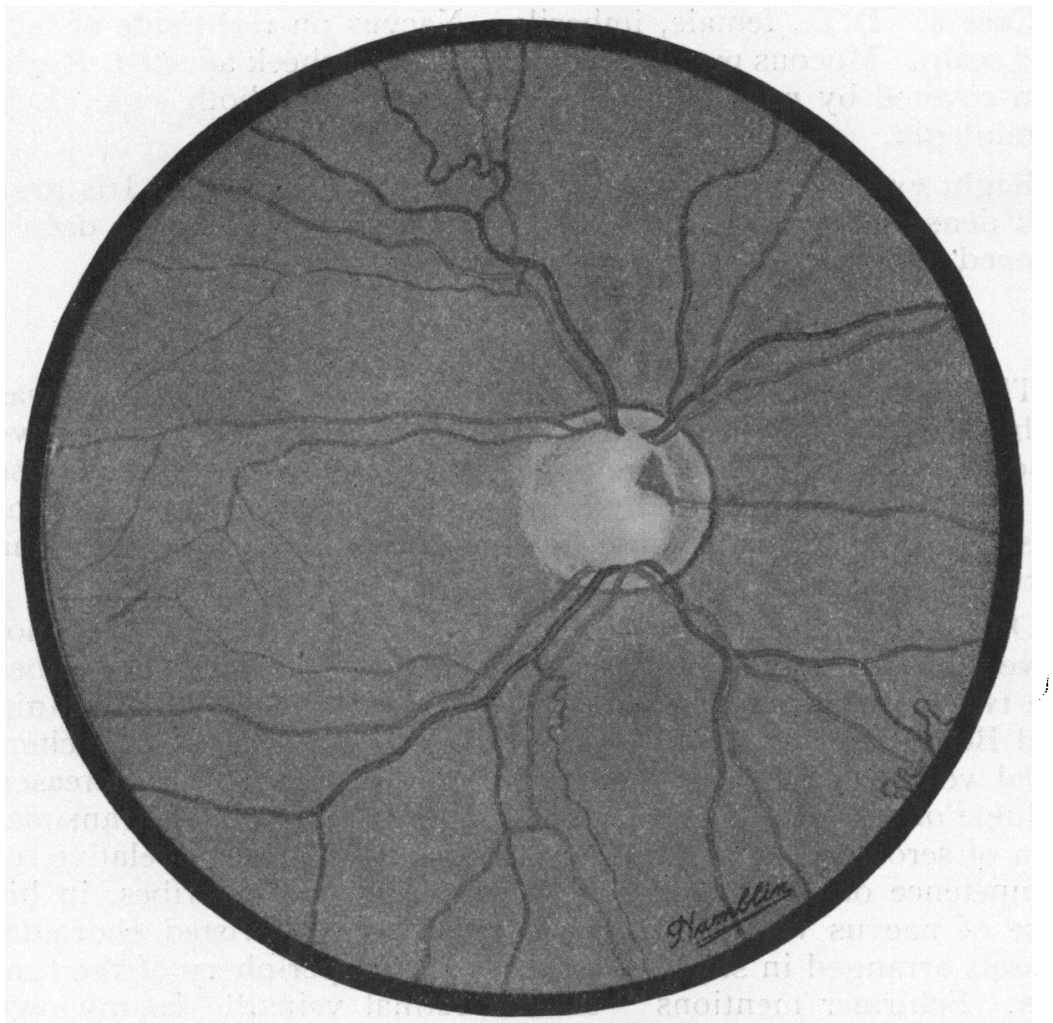

FIG. 4.

the skull shows a dark area above the cerebellum with a suspicion of commencing calcification in it.

Right eye-converges slightly. Is buphthalmic and the cornea is enlarged, but there is no thinning of the sclera. The iris has a dense stroma and is grey in colour, the normal side being blue. The disc is deeply cupped and appears atrophic. Vision, P.L. Tension full.

Case 3. B.G., female, imbecile. Naevus on both sides of the face, and areas on arms, back, and legs. Left hemiplegia. An 
$\mathrm{X}$-ray of the skull shows a circumscribed mass suggesting a calcified meningeal naevus, well marked in the cerebellar region.

Right eye-cornea enlarged about $13 \mathrm{~mm}$.; deep anterior chamber. Dense iris stroma darker in colour than normal side (Fig. 3). Optic disc large and deeply cupped. Retinal veins full and tortuous (Fig 4).

Case 4. D.T., female, imbecile. Naevus on right side of face and scalp. Mucous membranes of gums and cheek affected. Right arm covered by naevus. Areas on back and on both legs. Left hemiplegia.

Right eye-cornea enlarged, deep anterior chamber. Iris grey and dense in structure compared with normal side. Disc deeply cupped, especially on temporal side (coloured plate).

The first case of glaucoma in association with facial naevus was published by Schirmer in 1860 . About thirty cases have since been described. There appear to be two main groups, those in which a condition of hydrophthalmos is present at birth or arises early in life, and those in which acute or chronic glaucoma occurs in later life.

On account of the fact that many cases of facial naevi do not have glaucoma there have been differences of opinion as to whether the two conditions are in any way causally connected. Elschnig and Beltman think that a vascular change is present in the choroidal vessels similar to that in the skin, and that the increased volume of the vascular bed of the eye leads to increased transudation of serous fluid, both factors tending to produce a relative incompetence of the drainage mechanism. Salus describes, in his case of naevus with glaucoma simplex, broad twisted choroidal vessels arranged in stellate formation in the periphery of the fundus. Schirmer mentions " twisted retinal veins." In my own cases the globe has a faintly flushed appearance suggestive of some vascular engorgement but difficult to describe in detail and only noticed by comparison with the normal eye on the other side. The denser "sculptured" appearance of the iris and the consequent difference in colour from the normal side are very noticeable in all my cases. Knapp has described a case of glaucoma and naevus of the face in which microscopical examination of the iris showed it to be thickened and angiomatous. I believe that in these cases (and also perhaps in the related cases of conjunctival naevus with glaucoma) a similar vascular change might be found in the ciliary body and even in the choroid, either preventing the development of the canal of Schlemm or causing blocking of the filtration 


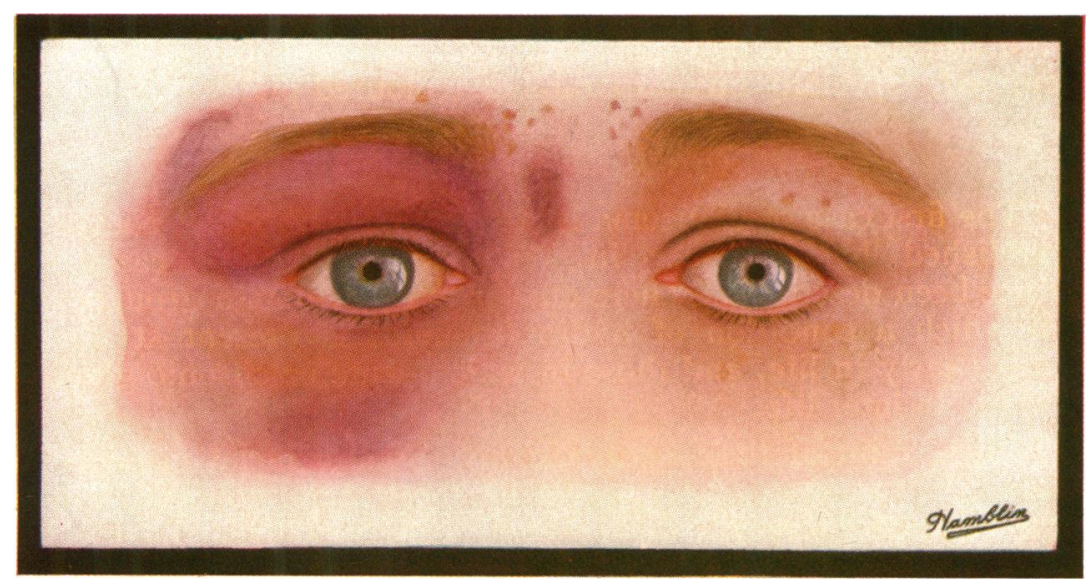

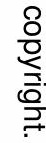


angle. Choroidal angioma might not be detected clinically in the absence of lesions in the retina, but E. E. Henderson and others have described such cases associated with facial naevus. [While this paper was in course of publication a case has been described by Krause with varicose iris vessels, and "enormously enlarged" peripheral choroidal vessels.]

Some observers favour the opinion that the connection between facial naevus and glaucoma is accidental, and an expression of the fact commonly observed that several congenital defects may be present in one person. Marchesani argues that as a naevus is a disorder of the skin vessels it is improbable that the same elective disorder would attack a part of the vascular system derived from the internal carotid artery. This opinion would appear to be untenable in the face of X-ray and operative reports demonstrating extensive meningeal vascular changes, and I hope to show that it is probably in the cases where there is intra-cranial involvement that eye defects are likely to arise. Safar, on pathological grounds, also rejects the idea of a causal connection between facial naevus and glaucoma and believes them to be merely co-existent abnormalities due to disease of the germinal layers. In a microscopical examination of his own case he found the ligamentum pectinatum thickened and the canal of Schlemm imperfectly developed in places. Safar's view is probably not correct for all cases, for Duschnitz has described a case in a young patient in whom no hydrophthalmos occurred (as would have been expected if some old-standing structural abnormality had been present) but the optic disc was cupped and the tension $40 \mathrm{~mm}$. It would seem more likely that a variable vascular rather than an architectural abnormality was present in this case.

However, there is no doubt that congenital abnormalities of the eye do apparently simply co-exist with facial naevi, though it is more likely that they have some common underlying cause. A. Fuchs has reported a case, and while this paper was in course of preparation interesting related cases have been described by Foster Moore, MacRae, and Thomson. The variety of cases is further increased by one described by Ginzberg in which glaucoma supervened in a congenitally abnormal eye with coloboma of the choroid. The tension was $60 \mathrm{~mm}$. and the disc deeply cupped. A facial and episcleral naevus was present in this case. (There is a possibility that some cases have been described as glaucomatous cupping which were merely congenital anomalies of the disc, and vice-versa.)

Cases of angiectasia solely of the eyeball seem to require mention, such as have been published by Leber, A. Fuchs, E. E. Henderson and James (with glaucoma). Bar reports a case of glaucoma with 
naevus of the eyeball, and in the fundus were seen numerous anastomoses between the venous areas. This condition appears to torm a link between the cases I am describing and von Hippel's disease, the picture of which has been further elaborated by Lindau who in addition to retinal angiomata found similar tumours in the cerebellum ; renal and pancreatic cysts, and suprarenal adenomata. In this respect a case recently described by Krause seems to form a true " missing-link," as in addition to buphthalmos and the evidence of cerebral involvement provided by one-sided spasms of the arm and leg, there is a liver enlargement thought clinically to be angiomatous.

In conclusion I would say that I have not had access to all the references on the subject, and in consequence may have overlooked some important points. Also that my own cases, partly for geographical reasons and partly on account of the almost insuperable difficulties of dealing with imbecile children, have not had as complete an examination as I should have liked. However, as an attempt to offer an explanation to cover the somewhat bewildering variety of cases I would express the opinion that facial naevus has in itself no causal relationship with glaucoma, but that where the general cause of facial and bodily naevi, either a toxin, or (as Unna suggests) slight trauma to the branchial clefts, acts to produce naevi of the cerebral vessels, then the mesoblastic structures of the developing eye may be affected. And this may lead either to imperfect formation of the filtration angle or canal of Schlemm, or to coloboma of the disc or choroid; or to a teleangiectatic condition of parts of the intra-ocular vascular system which may sooner or later, through growth, sclerosis, transudation, or haemorrhage lead to a disturbance of balance of the intra-ocular fluids and the production of increased tension.

I suggest with Parkes Weber and Foster Moore that cases of naevi (particularly fifth nerve distribution), cases of buphthalmos with facial or bodily naevi, and cases of von Hippel's disease should be examined by X-rays, and neurologically for the presence of intracranial lesions. A negative $\mathrm{X}$-ray of the skull may simply mean that the meningeal naevus has not yet calcified. I append a table of some cases with various points in favour of intracranial lesions.

I wish to express my thanks to Dr. Brushfield for permission to examine his cases ; to the Superintendent of the Fountains Hospital for allowing drawings to be made; and to Dr. J. L. Grout, of the Sheffield Royal Hospital, for his X-ray photographs and reports.

The drawing in Fig. 2 represents the condition present in all $\mathrm{my}$ cases and may be taken as their prototype. 
Evidence of Cerebral Lesions in Association with EyE LESIONS.

\begin{tabular}{|c|c|c|c|c|}
\hline Reporter. & Eye Exam. & $\begin{array}{l}\text { Neurological } \\
\text { Exam. }\end{array}$ & X-ray, etc. & Miscell. \\
\hline Aynsley (1) $\quad \ldots$ & L. buphth. & R. hemiplegia & $\begin{array}{l}\text { Calc. mening. nae- } \\
\text { vus. Abnormal } \\
\text { sella T. }\end{array}$ & Ment. def. \\
\hline Aynsley (2) $\quad \ldots$ & R. buphth. & L. hemiplegia & $\begin{array}{l}\text { S uggestive of } \\
\text { mening. naevus }\end{array}$ & ". \\
\hline $\begin{array}{l}\text { Aynsley (3) } \\
\text { (Brushfield's } \\
\text { case) }\end{array}$ & R. buphth. & L. hemiplegia & $\begin{array}{l}\text { Calc. mening. } \\
\text { naevus }\end{array}$ & ". \\
\hline $\begin{array}{l}\text { Aynsley (4) } \\
\text { (Brushfield's } \\
\text { case) }\end{array}$ & R. buphth. & L. hemiplegia & - & ". \\
\hline Brushfield $\quad \ldots$ & $\begin{array}{l}\text { Angioma "L. } \\
\text { sclerot ic } \\
\text { coat" }\end{array}$ & R. hemiplegia & $\begin{array}{l}\text { Calcified mening. } \\
\text { naevus. No sella } \\
\text { Turcica }\end{array}$ & " \\
\hline Cushing & R. buphth. & L. hemiplegia & $\begin{array}{l}\text { Necropsy. Nae- } \\
\text { void meninges }\end{array}$ & - \\
\hline Cushing & R. buphth. & $\begin{array}{l}\text { Convulsions } \\
\text { following } \\
\text { intracranial } \\
\text { haem. }\end{array}$ & $\begin{array}{l}\text { Operation, vascu- } \\
\text { lar dura c ad- } \\
\text { hesions }\end{array}$ & Ment. def. \\
\hline Cushing & R. buphth. & L. hemiplegia & - & ". \\
\hline Foster Moore ... & $\begin{array}{c}\text { Col ob o m a } \\
\text { L. dis }\end{array}$ & $\begin{array}{l}\text { Right homon. } \\
\text { hemiopia }\end{array}$ & $\begin{array}{l}\text { Calc. mening. } \\
\text { naevus }\end{array}$ & \\
\hline Macrae ... & $\begin{array}{r}\text { R. "pseudo } \\
\text { glaucoma" }\end{array}$ & $\begin{array}{l}\text { L. arm and leg } \\
\text { smaller than } \\
\mathrm{R} \text {. }\end{array}$ & & - \\
\hline Parkes Weber... & L. buphth. & R. hemiplegia & $\begin{array}{l}\text { Calc. mening. N. } \\
\text { Pit. fossa small }\end{array}$ & Ment. def. \\
\hline Thomson & L. macrophth. & $\begin{array}{r}\text { Paralytic attacks } \\
\text { L. arm and leg }\end{array}$ & - & ," \\
\hline Krause ... & L. buphth. & $\begin{array}{c}\text { Convulsive } \\
\text { att acks R. } \\
\text { arm and leg }\end{array}$ & - & Retarded \\
\hline
\end{tabular}

\section{REFERENCES}

1. Galezowski.-Ann. de Derm. et Syph., Vol. IX, p. 242, 1898.

2. Nakamura.-Klin. Monatsbl.f. Augenheilk., Vol. LXIX, p. 314, 1922.

3. Duschnitz.-Klin. Monatsbl. f. Augenheilk., Vol. LXX, p. 404, 1923.

4. Salus.-Klin. Monatsbl. f. Augenheilk., Vol. LXX, p. 540 ; Vol. LXXI. p. 305, 1923.

5. Safar.-Zeitschr.f. Augenheilk., Vol. LI, p. 301, 1923.

6. Zaun.-Klin. Monatsbl. f. Augenheilk., Vol. LXXII, p. 57.

7. Marchesani. Wiener Med. Wochenschr., Vol. LXXV, p. 2538, 1925.

8. Vita.-Soc. Italia di Ottal., p. 131, 1925.

9. Bar.-Dimmer Fest. Zeitschr., Vol. LVII, p. 628, 1925.

10. Ginzberg.-Klin. Monatsbl. f. Augenheilk., Vol. CLXXVI, p. 393.

11. Cabannes.-La Clin. Ophtal. September, 1909.

12. Cushing.-Modern Medicine, Vol. VI, p. 250, 1923. 
13. Knapp.-Trans. Amer. Ophthal. Soc., Vol. XXV, 1927.

14. Voegele.-Klin. Monatsbl.f. Augenheilk., Vol. LXXIV, p. 775, 1925.

15. Elschnig.-Zeitschr. f. Augenheilk., Vol. XXXIX, p. 189.

16. Parkes Weber. - Proc. Roy. Soc. of Med., 1929.

17. Brushfield and Wyatt.-Brit. Jl. of Children's Diseases, 1927 and 1928.

18. Aynsley.-Brit. Jl. of Children's Diseases, 1928.

19. MacRae.-Brit. Jl. of Ophthal., February, 1929.

20. Thomson, Ernest.-Brit. Jl. of Ophthal., March, 1929.

21. Foster Moore.-Brit. Jl. of Ophthal., May, 1929.

22. Henderson, E. E.-Brit. Jl. of Ophthal., 1920.

23. Milles.-Trans. Ophthal. Soc. U.K., 1884.

24. Lawford.-Trans. Ophthal. Soc. U.K., 1885.

25. Krause.-Zeitschr. f. Augenheilk., July, 1929.

26. Junius.-Zeitschr. f. Augenheilk. July, 1929.

\section{ANNOTATIONS}

\section{Ophthalmic School Inspection}

The Annual Report of the Metropolitan Asylums Board for the year 1928-29 has a short section devoted to ophthalmic conditions. As is well known ophthalmic cases among the L.C.C. schools have been under the care of the Board since 1897, and for the past five years cases of interstitial keratitis have been able to be admitted to the White-Oak School at Swanley.

Cases are drawn from the Metropolitan area, but, also by agreement, from extra-Metropolitan Boards of Guardians.

" To meet certain difficulties which had arisen in connection with children under the care of the Guardians and said to have a tendency to ophthalmia, arrangements were made by the Board in 1913 for monthly inspections by a surgeon skilled in the recognition and treatment of ophthalmia, of children at the Central London District School. The objects of this periodical visitation are, first, the earlier recognition and isolation of infective cases and a reduction in the number of cases which might otherwise be attacked by the disease and have to be dealt with specially by the Board in its ophthalmia school, and, secondly, to avoid occupation of accommodation by certain cases of a mild nature which are curable in a few days at their own institutions by means of suitable applications." These arrangements have worked well and are being continued.

The reports of the visiting ophthalmic surgeon at the Central London District School, Mr. F. A. C. Tyrrell, and of the visiting ophthalmic surgeon at White-Oak, Swanley, Mr. M. S. Mayou, are included. 